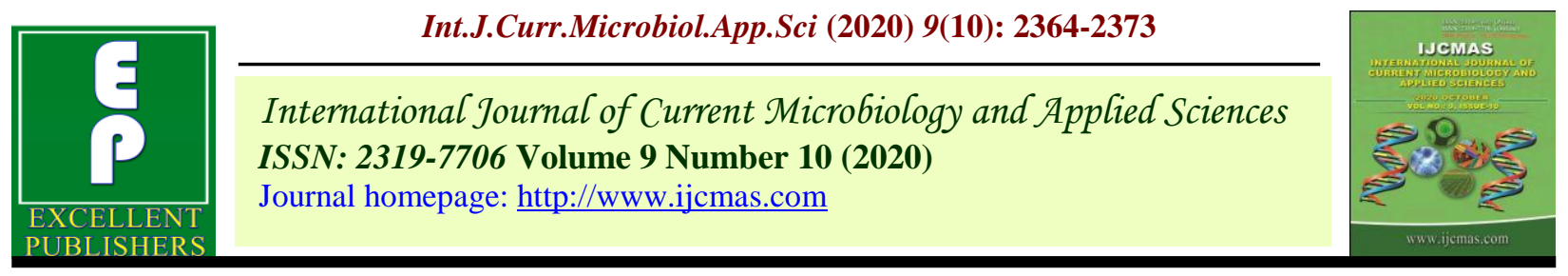

Original Research Article

https://doi.org/10.20546/ijcmas.2020.910.283

\title{
Improving the Powder Yield and Foaming Characteristics of Papaya Leaf Juice Treated with CMC (Carboxy-Methyl-Cellulose) and GMS (Glycerol-Mono-Stearate)
}

\author{
Mohit Bhardwaj $^{\text {** }}$, P.C Sharma ${ }^{1}$, Anil Kumar Verma ${ }^{1}$, \\ Chahat Thakur ${ }^{1}$, Raj Saini ${ }^{2}$ and Shivani ${ }^{1}$ \\ ${ }^{1}$ Department of Food Science and Technology, ${ }^{2}$ Department of Basic Sciences, College of \\ Horticulture and Forestry-Neri, Hamirpur, India \\ *Corresponding author
}

Keywords

Papaya leaf juice,

Foam mat drying,

Foaming properties,

CMC, GMS,

Drying, Powder

yield, Extraction

methods

Article Info

Accepted:

17 September 2020

Available Online:

10 October 2020

\section{A B S T R A C T}

The study was carried out for utilization of papaya leaf for preparation of foam mat dried papaya leaf powder. The conversion of papaya leaf juice into foam was optimized by whipping the juice after addition of carboxymethyl-cellulose (CMC) and drying the resultant foam in dehydrator $\left(60 \pm 2{ }^{\circ} \mathrm{C}\right)$ to constant moisture content. Drying of papaya leaf juice foam by using 3\% CMC results in 10.72 per cent powder yield and was found the most appropriate with respect to desired foaming properties (foam density, foam expansion and foam stability) and physical characteristics also. With the increase in the foaming agent concentration, the foam density decreases significantly however, the percentage of foam expansion was increased. In comparison to foam density, the papaya leaf juice exhibited higher foam expansion of 82.85 per cent with 3\% GMS in hot juice extract whereas, $3 \%$ CMC exhibited maximum foam density and foam stability of $0.562 \mathrm{~g} / \mathrm{cm}^{3}$ and 94.07 per cent. Thus, the papaya leaves can be utilized for preparation of self-stable powder using foam mat drying technique for further

\section{Introduction}

Papaya (Carica papaya L.) is one of the important fruits of tropical and subtropical regions in the world belonging to the family Caricaceae. The fruit is rich in $\beta$-carotene, vitamin- $\mathrm{A}$ and $\mathrm{C}$, iron, calcium, protein and phosphorus besides carbohydrates (Gopalan et al., 1972). Papaya tree is a large quick growing soft stemmed plant. The different parts of the papaya plant (the roots, stem, latex, leaves, fruits and seeds) are used in different preparations and also have been used for various pharmaceutical purposes as claimed traditionally for treatment of different aliments such as malaria, dengue and viral 
infections (Wiart, 2002). The dengue fever is one of the threatening diseases caused by dengue virus (Flavirus spp.) that is borne and transmitted by mosquitoes living in tropical and subtropical climates worldwide, mostly in urban and semi urban areas. As per the estimation of World Health Organization, every year, 50 million people across the world are infected by dengue and about 2/5th of the world population ( 2.5 billion peoples) are at risk from this dreadful disease, which spread over about 100 countries.

Dengue is also known as break-bone fever as it causes extreme body pain, especially in the bone joint. There have no effective medicine and vaccine approved for the dengue virus and developing a safe and effective antiviral drug is difficult, because viruses use the cells of the host to replicate. This makes it difficult to eradicate the virus without harming the host organism's cells (Kala, 2012).

Carica papaya leaf juice is consumed for its purported anti-cancer activity by people living on the gold coast of Australia. Carica papaya leaf juice has also been used for a long time as an aboriginal remedy for various disorders, including cancer and infectious diseases (Otsuki, 2009). The young leaves of papaya are eaten like spinach in some parts of Asia. According to Atta, (1999), the fresh papaya leaf is an antiseptic while dried papaya leaf is used as tonic and blood purifier. The papaya leaf juice is also used to increase platelets and white blood cells for normal clotting (Vijay et al., 2015).

Among the several methods of preservation, air drying is one of the common methods used for preservation of foodstuffs for extended shelf life. However, the quality of conventionally air-dried products is often lower compared to the original material, particularly the colour, rehydration ratio, texture, and other characteristics (Ratti,
2001). Dried juice products today are used mainly as convenience foods and have long storage life at ordinary temperatures.

Papaya leaf can be converted into value added product like powder by adopting a simple process technique (foam-mat drying). Foammat drying is one of the simple methods of drying in which a liquid food concentrate along with a suitable foaming agent is whipped to form a stable foam and is subjected to dehydration in the form of a mat of foam at relatively low temperature (Morgan et al., 1961).

Large quantity of papaya leaves are thrown as a waste. Development of product like beverages from papaya leaf can be an alternative for efficient utilization of leaves. However, bitter taste of the leaf extract makes the product unacceptable by the masses. Preparation of foam mat dried papaya leaf powder is an alternative for utilization of leaf extract in processed products with good pharmaceutical properties.

\section{Materials and Methods}

\section{Selection of fruits and foaming agents}

The fresh papaya leaves were procured from the fruit orchard of College of Horticulture and Forestry Neri, Hamirpur and nearby villages for use in experimentation for the preparation of foam mat dried papaya leaf powder. The papaya leaf juice extract was prepared by using cold and hot-pressed extraction method. In cold pressed extraction method, fresh leaves after washing were crushed in fruit mill and pressed/squeezed to extract juice through the screw type juice extractor and in hot pressed extraction method, boiling of crushed leaves along with $20 \%$ water by simmering for 10 minutes followed by squeezing to extract juice. 
Papaya leaf juice powder was prepared by converting the juice to a stable foam after using appropriate concentration of foaming agents such as Carboxymethyl cellulose (CMC) or Glycerol monostearate (GMS). The prepared foam from the papaya leaf juice was spread on suitable stainless-steel trays with a tray load rate of $100 \mathrm{~g} /$ tray in a thin layer (3$5 \mathrm{~mm}$ ) and dried in a mechanical dehydrator at $60 \pm 20 \mathrm{C}$ to a moisture content of about $5 \%$. After drying, the dried material was scrapped from the trays and further ground to a fine powder (Figure 1).

\section{Physical characteristics of papaya leaf}

\section{Leaf size}

Ten papaya leaves were randomly selected to measure the length and breadth with the help of a Vernier calliper and expressed as mean \pm $\mathrm{SD}$ in $\mathrm{cm}$.

\section{Weight}

Weight of randomly selected papaya leaves was measured with the help of weighing balance and expressed as mean $\pm \mathrm{SD}$ in $\mathrm{g}$.

\section{Visual color}

The fresh papaya leaves were evaluated for colour by visual appearance.

\section{Foaming properties}

The efficiency of foaming agent to convert the papaya leaf juice into a stable foam was optimized by evaluating various foaming properties as under:

\section{Foam density}

The density of the foamed papaya leaf juice was calculated as ratio of mass of foam to the volume of foam and expressed as $\mathrm{g} / \mathrm{cm} 3$
(Falade et al., 2003). The density of papaya leaf juice was determined by weighing $100 \mathrm{ml}$ of the juice in a $100 \mathrm{ml}$ measuring cylinder whereas for the foamed papaya juice, $200 \mathrm{ml}$ of foam was transferred into a $250 \mathrm{ml}$ measuring cylinder and weighed. The foam transferring was carried out carefully to avoid destroying the foam structure or trapping the air voids while filling the cylinder. The foam density was calculated using the following formula:

Mass of the foam, $\mathrm{g}$
Foam Density $\left(\mathrm{g} / \mathrm{cm}^{3}\right)=---\mathrm{of}^{3}$ Volume of the foam, $\mathrm{cm}^{3}$

\section{Foam expansion}

It is the percentage increase of the volume of the juice after foaming with required amount of the foaming agent and whipping time. The foaming quality of foamed papaya leaf juice in terms of foam expansion was calculated according to the following equation (Akiokatoet al., 1983):

Foam expansion $(\%)=\frac{\mathrm{V}_{1}-\mathrm{V}_{0}}{--------\times 100}$

Where, foam expansion is expressed in percentage (\%), V0 is the initial volume of the papaya leaf juice before foaming $(\mathrm{cm} 3)$ and $\mathrm{V} 1$ is the final volume of the papaya leaf juice after foaming (cm3).

\section{Foam stability}

$50 \mathrm{ml}$ foamed juice was placed in a $50 \mathrm{ml}$ glass tube and kept undisturbed at normal atmosphere for 2 hours (Marinova et al., 2009). Then, the decrease of the foam volume was noted after every 30-minute time interval. The reduction of the foam volume was noted to be used as an index for the determination of the stability after every 30 minutes by using following relationship: 
Foam Stability $(\%)=\frac{\mathrm{V}_{0}}{\mathrm{~V}_{1}}$

Where, foam stability is expressed in percentage (\%), V0 is the final volume of the papaya leaf juice after 2 hours of foaming and $\mathrm{V} 1$ is the initial volume of the papaya leaf juice after foaming.

\section{Powder yield}

After drying of foam in the mechanical dehydrator, dried material was scrapped from the trays and weighed to find out the powder recovery as follows:

Peight of powder
Weight of leaf extract

\section{Statistical analysis}

Data on physico-chemical characteristics was analyzed by completely randomized design (CRD). Data pertaining to the sensory evaluation of papaya leaf extract powder were evaluated by using randomized block design (RBD) according to Mahony (1985).

\section{Results and Discussion}

\section{Physical characteristics of papaya leaf}

Length and breadth of papaya leaves ranged between $63.0-71.3 \mathrm{~cm}(67.2 \pm 0.86)$ and 65.1$75.7 \mathrm{~cm}(70.21 \pm 1.13)$ respectively with a mean weight of $85.0 \pm 1.01 \mathrm{gm}$. All leaves used in the study were greenish to dark green in color (Table 1).

\section{Effect of foaming agents on foaming characteristics}

The results presented in Table 2 represent the foaming properties of both hot as well as cold juice extract while were converted into a foam by whipping for 5 minutes after addition of CMC (1-3\%) and GMS (1-3\%) as foaming agents in different concentrations.

\section{Foam density $\left(\mathrm{g} / \mathrm{cm}^{3}\right)$}

It is evident from Table 2 that hot juice extract exhibited significantly higher (0.601 $\mathrm{g} / \mathrm{cm}^{3}$ ) foam density as compared to foam density of cold juice extract $\left(0.594 \mathrm{~g} / \mathrm{cm}^{3}\right)$. Among different foaming agents, foam density ranged between 0.459 to $0.555 \mathrm{~g} / \mathrm{cm}^{3}$ and foam prepared by using CMC (1-3\%) exhibited higher density $\left(0.509-0.555 \mathrm{~g} / \mathrm{cm}^{3}\right)$ as compared to GMS $\left(0.459-0.523 \mathrm{~g} / \mathrm{cm}^{3}\right)$.

Kandasamy et al., (2012a) recorded foam density of fresh papaya pulp by using egg albumen as a foaming agent and found that the foam density start decreasing from 0.724 to $0.426 \mathrm{~g} / \mathrm{cm}^{3}$ and also decreased with increasing the level of foaming agent. According to Affandi et al., (2017) the reduction in foam density with increasing concentration of foaming agents was probably due to the reduction in the interfacial tension and surface tension of the pulp which form an interfacial film.

\section{Foam expansion (\%)}

It is revealed in Table 2 that foam expansion was significantly higher $(55.37 \%)$ in hot juice extract than that of cold juice extract $(50.11 \%)$. Among different foaming agents, use of GMS exhibited higher $(80.13 \%$ ) foam expansion as against 28.56-40.12 \% expansion in the foam obtained by using CMC. However, the interaction between the pulp and foaming agents significantly varied from 25.4 to $82.9 \%$. The maximum foam expansion was $82.9 \%$ in hot juice extract treated with 3\% GMS and minimum $25.4 \%$ foam expansion in cold juice extract treated with $1 \%$ CMC. While use of $3 \%$ CMC caused 
$40.06 \%$ expansion in foam of papaya leaf juice.

These observations conform to the findings of Shivani et al., (2019) who found that GMS exhibited higher $(19.4 \%)$ foam expansion in papaya pulp as against $7.3-13.3 \%$ foam expansion found by using CMC. Rajkumar and Kailappan (2006) recorded 45-328\% foam expansion in Totapuri mango pulp while Affandi et al., (2017) found 70.5$101.2 \%$ foam expansion in production of Nigella sativa beverage powder.

\section{Foam stability (\%)}

Data in Table 2 reveal that foam from hot juice extract exhibited significantly higher foam stability (79.7\%) as compared to cold juice extract $(77.9 \%)$. Among different concentration of foaming agents, it was found that with the increase in the concentration of foaming agents (1-3\%) the foam stability increased from 84.9 to $90.2 \%$ by using CMC and 67.3 to $73.2 \%$ by using GMS. Further, interaction between pulp and foaming agents varied from 65.1 to $94.1 \%$ with the maximum foam stability of $94.1 \%$ in hot juice extract treated with $3 \% \mathrm{CMC}$ and minimum $65.1 \%$ foam stability in hot juice extract treated with $1 \%$ GMS.

Earlier, Rajkumar andKailappan (2006) reported foam stability in Totapuri mango pulp ranging from 96.4 to $98.2 \%$ while Affandi et al., (2017) found 71.0 to $100.0 \%$ foam stability in Nigella sativa beverage powder.

\section{Powder yield $(\%)$}

Data given in Table 3 reveal that average yield varied from $6.91 \%$ to $10.72 \%$ in cold juice extract and hot juice extract powder prepared by using different concentrations of foaming agents. As expected, the dried powder from cold juice extract as such without using foaming agents gave lower yield $(6.91 \%)$ while foaming of hot juice extract brought a significant increase in yield of the dried powder. Mean yield from unfoamed control juice was $7.25 \%$ which increased to 8.26 to $10.07 \%$ in foamed juice by using CMC (1-3\%) and 7.39 to $8.88 \%$ by using GMS (1-3\%) foaming agent.

Among cold and hot juice extract, the maximum yield of $8.78 \%$ was obtained in hot juice extract as compared to cold juice extract $(8.20 \%)$. Higher yield of powder from hot juice extract was attributed to the extraction of higher solids in hot juice extract as compared to cold juice extract. Further, interaction between type of juice and foaming agents was also found to be significant for yield of papaya leaf extract.

Similar results with increase in concentration of foaming agents have been reported by Sharma et al., (2002) in foam mat dried hill lemon juice powder (8.03-11.18 \%). Also, Shivani et al., (2019) reveal that average yield of papaya powder varied from $10.10 \%$ to $11.93 \%$ in natural and sweetened pulp powder among different concentration of foaming agents

\section{Drying time}

The papaya leaf juice after converting in to foam by using different foaming agents was dried in a cabinet drier at $60 \pm 2^{\circ} \mathrm{C}$. The time taken for drying of foam to a constant weight was evaluated in different treatments.

Data in Table 4 and Figure 2 reveal that average drying time for dehydration of different types of foamed juice extract with different concentration of foaming agents varied between 9.52 to 13.02 hours. The effect of foaming agents on foam mat drying of juice extract is also presented in Figure 2. 
As expected, the hot juice extract dried as such without using foaming agents, took the longest (13.02 hours) time for drying while foaming of juice extract brought about significant reduction in drying time of the juice extract. Mean drying time for un-foamed control juice extract was 12.16 hours which reduced to 10.37 to 11.73 hours in foamed pulp by using CMC (1-3\%) and 11.13 to 11.93 hours in papaya leaf juice extract foamed by using GMS (1-3\%) foaming agent. Among cold and hot juice extract, the time taken for drying of the foam ranged between $10.78-12.12$ hours.

Further, the interaction between type of juice and foaming agents were also found to be significant for the drying time. Earlier, Kandasamy et al., (2012b) have observed that the time taken for drying of foamed papaya pulp at $60^{\circ} \mathrm{C}$ was $3,4,7$ and $9 \mathrm{~h}$ for $2,4,6$ and $8-\mathrm{mm}$ thick foam respectively. While time taken for drying of non-foamed papaya pulp was substantially high i.e, 6, 8, 10 and 12 $\mathrm{h}$ for $2,4,6$ and $8 \mathrm{~mm}$ thick respectively. Sharma et al., (2002) have reported higher (20.30 hours) time for non-foamed hill lemon juice powder as compared to foamed lemon juice (19.40-17.15 hours). The reduction in drying time with increase in concentration of foaming agents could be due to the increase in porosity of the foamed sample which allows faster movement of dry air.

Table.1 Physical characteristics of papaya leaf

\begin{tabular}{|c|c|}
\hline Attributes & Mean \pm S. D \\
\hline Length $(\mathbf{c m})$ & $67.2 \pm 0.86$ \\
\hline Breadth $(\mathbf{c m})$ & $70.2 \pm 1.13$ \\
\hline Weight $(\mathbf{g})$ & $85.0 \pm 1.01$ \\
\hline Visual color & Greenish-to- dark green \\
\hline
\end{tabular}

Table.2 Effect of foaming agents on foaming characteristics of papaya leaf juice

\begin{tabular}{|c|c|c|c|c|c|c|c|c|c|c|}
\hline \multirow{3}{*}{$\begin{array}{l}\text { Foaming } \\
\text { Agents }\end{array}$} & \multirow{3}{*}{$\begin{array}{c}\text { Concentration } \\
(\%)\end{array}$} & \multicolumn{9}{|c|}{ Foaming Characteristics } \\
\hline & & \multicolumn{3}{|c|}{$\begin{array}{l}\text { Foam Density } \\
\qquad\left(\mathrm{g} / \mathrm{cm}^{3}\right)\end{array}$} & \multicolumn{3}{|c|}{$\begin{array}{c}\text { Foam Expansion } \\
(\%)\end{array}$} & \multicolumn{3}{|c|}{$\begin{array}{c}\text { Foam Stability } \\
(\%)\end{array}$} \\
\hline & & CJE & HJE & Mean & CJE & HJE & Mean & CJE & HJE & Mean \\
\hline \multirow[t]{3}{*}{ CMC } & 1.0 & 0.508 & 0.601 & 0.555 & 25.38 & 28.56 & 26.97 & 81.72 & 88.00 & 84.86 \\
\hline & 2.0 & 0.487 & 0.581 & 0.534 & 34.32 & 34.97 & 34.64 & 83.87 & 90.42 & 87.14 \\
\hline & 3.0 & 0.456 & 0.562 & 0.509 & 40.00 & 40.12 & 40.06 & 86.28 & 94.07 & 90.17 \\
\hline \multirow[t]{4}{*}{ GMS } & 1.0 & 0.594 & 0.451 & 0.523 & 59.37 & 71.42 & 65.40 & 69.57 & 65.07 & 67.32 \\
\hline & 2.0 & 0.546 & 0.439 & 0.493 & 64.19 & 74.27 & 69.23 & 72.10 & 67.68 & 69.89 \\
\hline & 3.0 & 0.496 & 0.421 & 0.459 & 77.41 & 82.85 & 80.13 & 73.80 & 72.66 & 73.23 \\
\hline & Mean & 0.515 & 0.509 & & 50.11 & 55.37 & & 77.89 & 79.65 & \\
\hline \multicolumn{2}{|c|}{$\begin{array}{c}\text { CD0.05 } \\
\text { Juice }(\mathbf{J}) \\
\text { Foaming agent(F) } \\
\text { J x F }\end{array}$} & \multicolumn{3}{|c|}{$\begin{array}{l}0.001 \\
0.001 \\
0.002\end{array}$} & \multicolumn{3}{|c|}{$\begin{array}{l}0.010 \\
0.006 \\
0.014\end{array}$} & \multicolumn{3}{|c|}{$\begin{array}{l}0.016 \\
0.009 \\
0.022\end{array}$} \\
\hline
\end{tabular}

Where, CMC $=$ Carboxy methyl cellulose, GMS = Glycerol mono stearate, CJE= Cold Juice Extract, HJE $=$ Hot Juice Extract 
Table.3 Effect of foaming agents on yield (\%) of foam mat dried papaya leaf extract powder

\begin{tabular}{|c|c|c|c|c|}
\hline \multirow[t]{2}{*}{ Foaming agents } & \multirow[t]{2}{*}{ Concentration (\%) } & \multicolumn{3}{|c|}{ Yield (\%) } \\
\hline & & CJE & HJE & Mean \\
\hline \multirow{4}{*}{ CMC } & Control & 6.91 & 7.59 & 7.25 \\
\hline & 1.0 & 8.02 & 8.50 & 8.26 \\
\hline & 2.0 & 8.91 & 9.83 & 9.37 \\
\hline & 3.0 & 9.41 & 10.72 & 10.07 \\
\hline \multirow{3}{*}{ GMS } & 1.0 & 7.48 & 7.31 & 7.39 \\
\hline & 2.0 & 7.99 & 8.39 & 8.19 \\
\hline & 3.0 & 8.65 & 9.11 & 8.88 \\
\hline \multicolumn{2}{|c|}{ Mean } & 10.78 & 8.20 & 8.78 \\
\hline \multicolumn{2}{|c|}{$\begin{array}{l}\mathrm{CD}_{0.05} \\
\quad \text { Juice }(\mathbf{J}) \\
\text { Foaming agent }(\mathbf{F}) \\
\mathbf{J} \times \mathbf{F}\end{array}$} & \multicolumn{3}{|c|}{$\begin{array}{l}0.024 \\
0.013 \\
0.033\end{array}$} \\
\hline
\end{tabular}

Where, $\mathrm{CMC}=$ Carboxy methyl cellulose, GMS $=$ Glycerol mono stearate, $\mathrm{CJE}=$ Cold Juice Extract, HJE $=$ Hot Juice Extract, Control $=$ Powder obtained from juice without using foaming agents.

Table.4 Effect of different foaming agents and their concentration on drying time of papaya leaf juice extract

\begin{tabular}{|c|c|c|c|c|}
\hline \multirow[t]{2}{*}{ Foaming agents } & \multirow[t]{2}{*}{ Concentration (\%) } & \multicolumn{3}{|c|}{ Drying Time (hours) } \\
\hline & & CJE & HJE & Mean \\
\hline \multirow{4}{*}{ CMC } & Control & 11.30 & 13.02 & 12.16 \\
\hline & 1.0 & 11.13 & 12.34 & 11.73 \\
\hline & 2.0 & 10.41 & 12.00 & 11.21 \\
\hline & 3.0 & 9.52 & 11.23 & 10.37 \\
\hline \multirow{3}{*}{ GMS } & 1.0 & 11.32 & 12.54 & 11.93 \\
\hline & 2.0 & 11.02 & 12.24 & 11.63 \\
\hline & 3.0 & 10.78 & 11.49 & 11.13 \\
\hline \multicolumn{2}{|c|}{ Mean } & 10.78 & 12.12 & \\
\hline \multicolumn{2}{|c|}{$\begin{array}{l}\mathrm{CD}_{0.05} \\
\quad \text { Juice }(\mathbf{J}) \\
\text { Foaming agent }(\mathbf{F}) \\
\mathbf{J} \times \mathbf{F}\end{array}$} & & $\begin{array}{l}0.024 \\
0.013 \\
0.033\end{array}$ & \\
\hline
\end{tabular}

Where, $\mathrm{CMC}=$ Carboxy methyl cellulose, GMS = Glycerol mono stearate, CJE= Cold Juice Extract, HJE= Hot Juice Extract, Control= Powder obtained from juice without using foaming agents. 
Figure.1 Flow sheet for preparation of foam mat dried papaya leaf juice powder

Figure 1 Flow Sheet for preparation of foam mat dried papaya leaf juice powder.

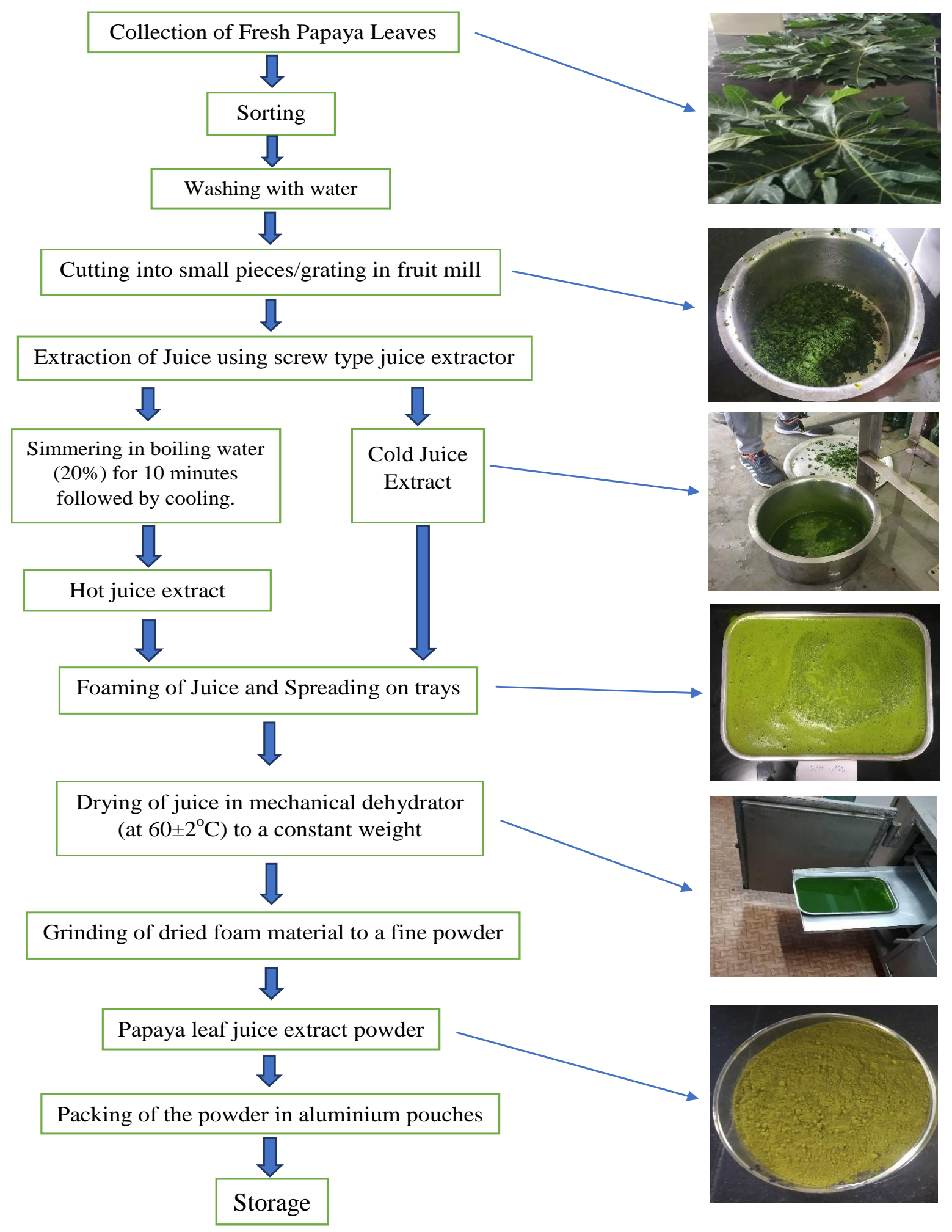


Figure.2 Effect of foaming agents on drying time of papaya leaf juice extract

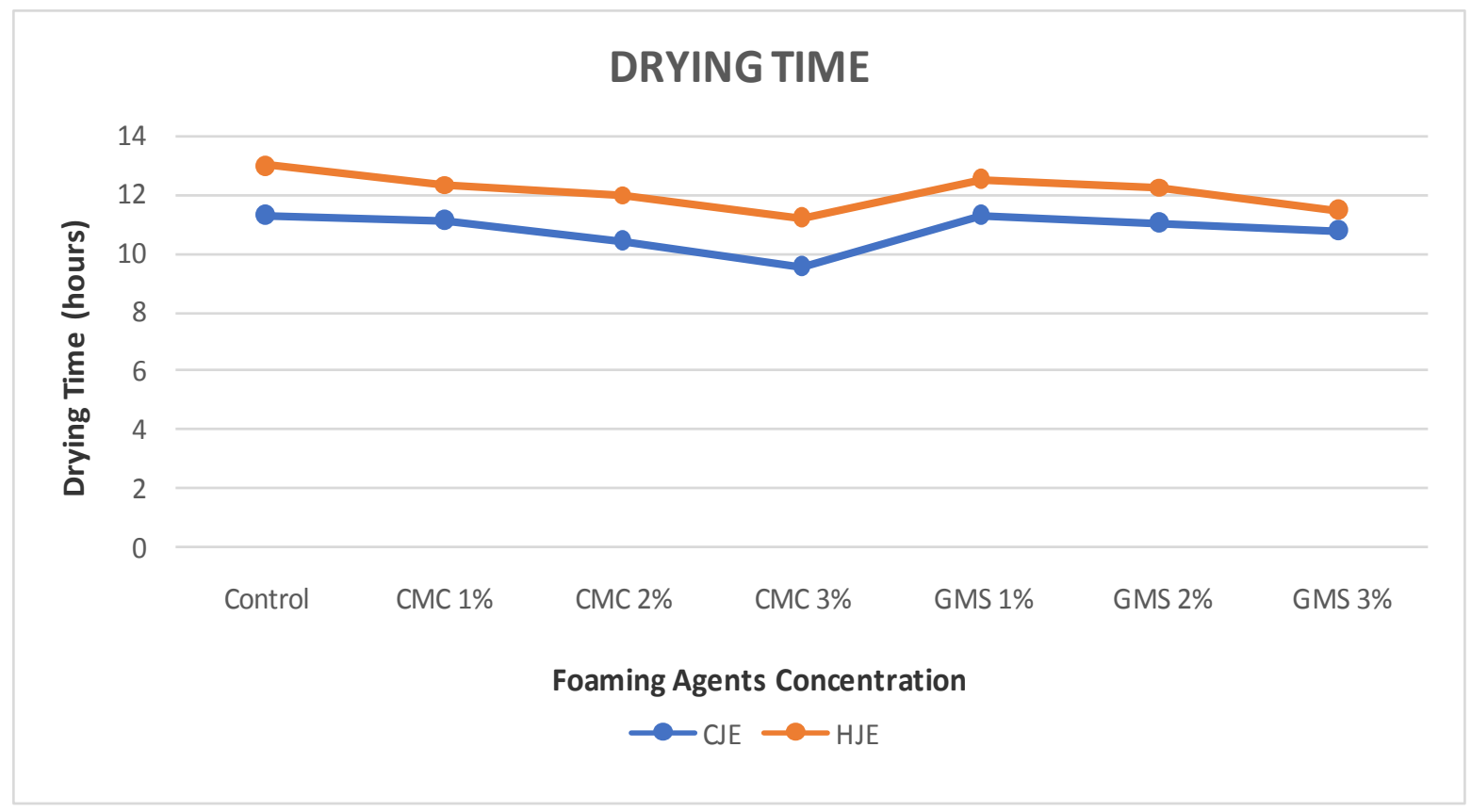

\section{References}

Affandi, N., Zzaman W, Yang T. A. and Easa A. M. 2017. Production of Nigella sativa beverage powder under foam mat drying using egg albumen as a foaming agent. Beverages 3:1-15.

Akiokato, A. T., Matsudomi N and Kobayashi K. 1983. Determination of foaming properties of egg white by conductivity measurements. Journal of Food Science and Technology 48(1): 62-65.

Atta, K. B., 1999. The power of Garlic Cardiovascular disease prevention association, Buea, Cameroon, pp.72.

Falade, F. O., Adeyanju K. I. and Uzo-Peters P. I. 2003. Foam mat drying of cowpea (Vigna unguiculata) using glyceryl monostearate and egg albumen as foaming agents. Food Research Technology 217: 486-491.

Kala, P. C., 2012. Leaf juice of Carica papaya: A Remedy of Dengue Fever, Medicinal \& Aromatic Plants 357.

Kandasamy, P., Varadharaju N, Kalemullah S and Moitra R. 2012a. Preparation of papaya powder under foam-mat drying technique using egg albumin as foaming agent. International Journal of Bioresource and Stress Management 3(3): 324-331.

Kandasamy, P., Varadharaju N and Kalemullah S. 2012b. Foam-mat drying of Papaya (Carica papaya L.) using glycerol monostearate as foaming agent. Food Science and Quality Management 9: 17-27.

Otsuki, N., Dang N. H., Kumagai E, Kondo A, Iwata S and Morimoto C. 2010. Aqueous extract of Carica papaya leaves exhibits anti-tumor activity and immunomodulatory effects. Journal of Ethnopharmacology 127: 760-767.

Mahony, M. O., 1985. Sensory evaluation of food: Statistical methods and procedures. Marcel Dekker Inc., New York. p: 132.

Marinova, K. G., Basheva E. S., Nenova B, Temelska M, Mirarefi A. Y., Campbell B and Ivanov I. B. 2009. Physico- 
chemical factors controlling the formability and foam stability of milk proteins: Sodium caseinate and whey protein concentrates. Food Hydrocoll 37:498-506.

Morgan, A. I., Graham R. P., Ginnette L. F. and Williams G. S.1961. Recent developments in foam-mat drying. Food Technology 15: 37-39.

Rajkumar, P., and Kailappan R. 2006. Optimizing the process parameters for foam mat drying of Totapuri mango pulp. Madras Agriculture Journal 93(6): 86-98.

Ratti, C., 2001. Hot air and freeze drying of high value food: a review. Journal of Food Engineering 49: 311-319.

Sharma, P. C., Sharma S. K. and Kaushal B.
B. 2002. Studies on the preparation of foam mat dried hill lemon (Citrus pseudolimon Tan.) juice powder. Indian Food Packer 56(4): 67- 71.

Shivani., Verma A. K., Sharma P.C., Gupta A and Kaushal M. 2019. Effect of foaming agent on quality and yield of foam mat dried papaya powder. International Journal of Current Microbiology and Applied Sciences 8(12): 2821-2835.

Wiart, C., 2002. Medical plants of Southern Asia. Prentice hall Pearson Malaysia Sdn. Bhd. 2ed. pp. 395.

Vijay, Y., Pradeep K. G., Chetan S. C., Anju $\mathrm{G}$ and Bhupendra V. 2015. Carica papaya linn: An overview. International Journal of Herbal Medicine 5: 01-08.

\section{How to cite this article:}

Mohit Bhardwaj, P.C. Sharma, Anil Kumar Verma, Chahat Thakur, Raj Saini and Shivani. 2020. Improving the Powder Yield and Foaming Characteristics of Papaya Leaf Juice Treated with CMC (Carboxy-Methyl-Cellulose) and GMS (Glycerol-Mono-Stearate). Int.J.Curr.Microbiol.App.Sci. 9(10): 2364-2373. doi: https://doi.org/10.20546/ijcmas.2020.910.283 